International Journal of Education (IJE), Vol. 3, No. 3, September 2015

\title{
ASSESSING THE PSYCHOLOGICAL DISPOSITION OF COLLEGE STUDENTS ON FUNCTIONAL EDUCATION AND NATIONAL DEVELOPMENT IN NIGERIA
}

\author{
Dr. A. A. Ladan \\ Department Of Educational Psychology, \\ Federal University Of Education Zaria
}

\begin{abstract}
:
The study focused on finding out the psychological disposition of university student teachers on the functional capacity of the educational system in Nigeria and its impact on national development. The research design employed was survey method. Three hypothesis were raised and tested at 0.05 alpha level of significance. The population of the study includes all the 200 level students' teachers of Ahmadu Bello University Zaria and Othman Danfodio University Sokoto which is made up 2,058 students. 200 participants were selected for the study using simple random sampling model. Instrument used for the study was a self - developed questionnaire. Correlational analysis was employed in analyzing the data collected. The study revealed from all indications that there is a significant relationship between student teachers psychological disposition and functional education in Nigeria. Students' perception positively correlated with functional education. Attitude was found to positively relate with functional education. By implication, the system demands more proactive practical approach in order to make it more functional so as to fit into the current global trend in education. The recommendation is that the functional level of Nigerian education should be increased.
\end{abstract}

\section{Keywords:}

Assessment, Psychological disposition, College Students, Functional Education, National Development.

\section{Introduction:}

Education is a vital tool for national development in every nation (Chima, 2007). It plays vital role in determining the development of economic, social, political, and moral state of the people and creates national consciousness. The social welfare and economic advancement of individual members of the society is enhanced by their level of educational attainment. With effective education, individuals can be assured of better future prospects. In other words, education holds sway to the future prospects of a nation.

Furthermore, education goes a long way to develop the intellectual and moral abilities of a student in order to develop the capability of creative potentials that lead to creative activities, which will eventually have direct link or connection to the student's daily life (Zeilberge, 1999).In essence, functional education is an important factor in education because of its scientific

DOI : $10.5121 /$ ije. 2015.3303 
International Journal of Education (IJE), Vol. 3, No. 3, September 2015

foundation and practical based activities that facilitate greater acquisition of knowledge as well as understanding of learned material and the ability to relate it to daily academic activities and other life functions. Obinne and Adikwu (2007) conducted a study on the factors influencing the aspiration of the Nigerian child; it was found that on the aspect of carrier choice, Medicine and Engineering were ranked higher by the respondents. This can be attributed to the fact that these two professions are functional in nature. It can also be an indication that Nigerian youths are craving for functional education that will keep them going by equipping them with relevant skills required for successful living and engagement. Delong and Winter (2002) asserted that functional education produce fascinating experiences to the learner and help them develop the sense of relevance. This in essence leads to development of personal commitment and contribution to national development. Kayode and Adagba (2014), asserts that education is the bedrock of the socio- economic and political development of any nation. Developed countries of the world like China, Japan, Russia, and United States of America among others have achieved various breakthroughs due to their commitment to ensuring a functional educational system in their countries.

Functional education ensures and influences effective development of the learner's potentials. It empowers individuals for quality contribution to the development of the society (Chima, 2007), this also agrees with the contribution of Addo-Adeku (1992), Dorvlo (1992), and Freire (1992) that functional literacy could be used to improve social, economic and environmental problems. A positive relationship can therefore be said to exist between functional literacy and development. According to Rehab management (2012) functional education is an evidence based education intervention that utilizes every day academic activities and exercise to help learners increase their creative and imaginative capacities which will enable them to carry out educational activities comfortably. Balo (2003), viewed it as education that is relevant to the needs of the people which would facilitate self-reliance. Molagun (2008) sees as a systematic study of techniques for making and doing things through with can be regarded as a Vocational education which purposely designed to make individuals fit for gainful employment in recognized trade as semi-skilled workers or professionals.

When members of a society are adequately equipped with effective education, which is refers to functional education, they can impact in the nation's socioeconomic, political, educational, and national development as well as the entire social wellbeing of the nation. In accordance with Molagun, (2008), any educational system that can be said to be a quality education can also be referred to as functional education. Hence, manpower need for the nation can commonly be achieved through such educational system. Education gives credence to the level of civilization that people desire at any given time. The value of education can only be appreciated by individual members of the society when the educational system or process can effectively impact on their lives by helping them to achieve their aspirations. People engage in these learning processes that are interesting, stimulating and also inspires curiosity that facilitate further effort and spirit of enquiry (Middton, n.d). Hence such level of education process produces self-discovery, and that is enhancing and fascinating, leads to innovation and technological advancement of both individuals and the society as a whole.

Education also awakens in the citizenry the consciousness of value system and sense of good judgement which will enable them to differentiate between right and wrong values (Chima, 2007). Acquisition of education makes one a valuable entity that can impact on the lives of others around. 
International Journal of Education (IJE), Vol. 3, No. 3, September 2015

According to Ukoha (2007:85), "the basic idea of education is to acquire knowledge that makes one a better person who can contribute meaningfully to the development of self and society".

Kolawale (2005), notes that education is a major tool of individuals and for promoting peace and order in the society. National Policy on Education (2004), presents education as a tool for national development. Conversely, several governments in Nigeria have argued that education remains the wheel on which the country's development revolves (The Politico 2011).

\section{Literature Review}

\subsection{Functional Education conceptualization}

In the psychological perspective of functional education, especially as expressed by William James in Zeilberger (1999) which was later expanded by Eduard Claparede, functional education is viewed as the wholeness of the psychic phenomena which attributes value to the role in the adaptation of an organism to its natural and social environment. According to Claparede in Zeilberger (1999), a living organism is a system that strives to preserve its wholeness and equilibrium so that when it is in danger of collapse, it tends to bring itself back to its original state. Disposition in the other hand is adjudged as approximately equivalent to a prevailing frame of mind or spirit (American Heritage Dictionary of English language, 2009). Collins dictionary defines it as one's usual mood, temperament, a habitual inclination, or a tendency. To psychological view, it is referred to as natural or acquired tendency, inclination, or a habit in the individual. Free dictionary (2013) looked at it from the point of view of personal temperament or frame of mind. In essence disposition implies an individual's usual mood, temperament, habitual propensity to act in a certain way at any given situation. It is a behavioural manifestation of innate tendencies in an individual to act in a specific way. It can also be viewed as an expression of one's position towards a particular issue.

Furthermore, Asaju and Adagba (2014), viewed functional education as an education that equips the recipient with the knowledge and skills needed for that performance of productive task, $t$ is also one that helps the society meet their developmental needs. National development of any nation to a large extent depends on the type of educational system dominant in that country has. This is also attributed to the type of human resource available le to the nation. Any society that can see the light of the day in terms of development should consider the adequacy of its educational process. is produced. The educational system of any nation determines its type, nature and calibre of any power o be supplied. The educational system and the commitment to human resource development have been attributed to their level of achievement and other breakthroughs experienced in these countries. The economic success of the so called 'Asian tiger' has been attributed to the educational system which are functional and the priorities given to human resource development among these developed nations.

Examination of the aforegoing approaches to learning (inductive and deduction) reveals that, functional education is one which develops a reconciliation or balance between process and content (or concept) based approaches. 
International Journal of Education (IJE), Vol. 3, No. 3, September 2015

It (functional education) brings together the relevant content and life skills, as the child metamorphoses into a responsible contributing adult in the society.

\subsection{Functional impact of functional education}

Functional education implies an educational system that provides opportunities for learners to acquire practical skills and knowledge which will enhance their functionality in the society, especially in the work place and labour market. According to Zeilberger (1999), functional education is an educational system that meets the needs of the learner, that acts in the interest of the child, a mechanism for motivating the learner in order to achieve the child's desired educational and life objectives. The main intention of functional education is to develop learners to the extent of making meaning out of life both on the present and in the future. For functional education to be realistic, the instructional process must also be functional (Zeilberger, 1999). This means that the learning process should be practical based, skill impacting, knowledge bound, and life touching, so that the child's environment can adequately benefit from the impact of such education (Zeilberger, 1999), According to him, to educate implies adapting the child to his environment, while emphasizing his needs and inclinations, as they are revealed in his developmental stages. Literature report is demonstrating the import of functional education wherever it is institutionalized. In accordance with the views of Kayode and Adagba (2014) that some major developed nations are right now enjoying the benefit of functional education in their countries due to their commitment to its operations According to them these nations have achieved developmental breakthrough despite the fact that some of them are not endowed with any natural resource. The secret of their breakthrough is traceable to their commitment to functional educational system. Maintaining a standard educational system that would positively affect the basic foundations of educational growth and development. Asaju et.al (2013) study report showed that declining standard of education in Nigeria has affected its efforts at human

resource development with great consequences for government efforts at reducing the high rate of poverty, unemployment, inequality which are attributed for other social ills experienced in the country today.

Furthermore, Zeilberger (1999:3), asserts that "functional Education is based on the natural need of the child to enquire and to know, to observe and to work, and especially to play; it strives to arouse in the child spiritual longing, like the love of the good (for doing good) and for work, that will not come by force, but rather in a free atmosphere and in suitable living conditions; for that purpose, the school should create a lively and happy environment, where the child will act enthusiastically". It creates opportunity for students to develop intuitive and imaginative concepts in learning which helps them to master the skill of what is learned and adopt the knowledge to achieve meaningful and valuable actions or activities. To a large extent, when an education system is functional, it embraces the fundamental requirements of a quality education as well as an educational system that will be valued by all and sundry. According to Rehab management (2012), functional education increases the performance level of individuals, reduces the incapacity of individuals because of acquired proficiency through constant engagement in activities. It empowers a student's ability to control the learning situation and achieve good success. It is a fact that it remains the most potent educational system capable of producing the required critical mass of technicians who can use their skills and turn the country into one of the new emerging global great economies (The Politico, 2011). 
International Journal of Education (IJE), Vol. 3, No. 3, September 2015

In line with the thought of Molagun (2008), functional education prevents poverty, as well as dependence on others for most individual needs. It also empowers its recipients for successful endeavours within the environment and the society at large. It im port lies on the fact that it provides opportunity for productive contribution of its beneficiaries to the society. It provides the avenue for self-reliance and dependency. Nigerian graduates roam about the streets in search of unavailable jobs due to the fact the education they acquired did not make provision for personal engagement after school (Molagun, 2008). Functional education enhances realization of national objectives in a faster dimension. It fast tracks the level of civilization of a people and gives them a place of pride among the committee of nations. In essence, functional education facilitates the production of quality man power requirement of a country. Hence, the type, quality, caliber of that man power available to a society is traceable to the quality functional education in the nation. The extent the members of a society can advance, contribute and facilitate the upward movement of their people and nation is determined by the type of education they acquire. Asaju and Adagba (2014) opines that through functional education, qualitative manpower

Other authors have explained functional education from different dimensions Ocho 2005 in Agbo (2014), sees functional education as that process through which an individual is transformed into a participant in the social and economic development of his society. In the same way, Unachukwu (2009), holds view that because functional education gives the individual the opportunity of living within and contributing to the economic development of his society, a functional educational system takes cognizance of the dynamics of the labor market, equips its graduates with occupational skills and competencies to enable them be self- reliant. If citizens of a country would be self-dependent, and make adequate impact in their society, functional education is the only educational system that should provide the plat form upon which they should ride to succeed. The educational system in a country has a lot to do with the level of development obtainable in that country. It was on this premise that Nwaka (2012) observed that national development hinges on the kind of educational exposure the citizens have. It is only functional education that can make an individual productive and self-reliant. No wonder many nations have made pronouncements and efforts at using meaningful and necessary educational programmes to equip their youths with knowledge, values, attitudes and skills deemed necessary for them to preserve their values; function effectively and contribute to the overall development of the nation.

The development drive that can move a nation to the point real development which can match the rate of drive obtainable globally, must be dependent on the functional level of education in the nation. To meet up with global demands in education, socioeconomic, political, socially, and competitively presently demands a high level functional education system. Nwaka (2012) opines Presently, Nigerians live in a changing world and as a result of research findings, new information, knowledge, approaches, methods of instruction and resources emerge. In the same vein, Offorma, (2010) noted that teachers are expected to keep abreast of such innovations so as to produce functional citizens, who would contribute to the development of the society. Nigeria needs education that would be practical and skill development-oriented or functionally-driven to fortify its youths with skills needed to perform contemporary tasks (Nwaka, 2012). Nigeria considering her place in global politics today supposed to have viral functional education that can reflect in her citizens so as to enable fit into the highly demanding global environment and make impact on it. Nigeria's product should be a product of functional force that could move and impact global economy. This is the type of educational system would market the country and 
International Journal of Education (IJE), Vol. 3, No. 3, September 2015

make it enviable among committee of nations. Nigerians could be proud of their country since they themselves would be the beneficiaries of that development.

\subsection{Values, Attitude, and Perception of Functional Education}

Values are described as criteria for determining levels of goodness, worth or beauty. It implies an expression of feeling, or the acquisition of and adherence to a set of principles, rules, and norms of a people or personal set standards of behaviour (Nayak and Rao, 2004). Values provide important filter for selecting inputs, connecting thoughts and feelings to action. It also provides platform for life success. Value in education sector refers to explicit process to teach individuals about values (Nayak and Rao, 2004). Student's ability to identify with standards or rules of behaviour implies the process of acceptance of and internalization of the values which eventually act as guide to good behaviour system. It creates opportunities for the individual to appreciate the educational system being provided by the society as well as what education provides for national development. Nayak and Rao (2004:137) assert that "a person's action is the result of his or her feelings, thoughts, behaviours, and experiences". The way individuals receive and respond to the education in their society depends on the value they place on such educational system. On this, Onyechi (2014), noted that a country that denies education to its people denies them and their country a future ; denies them civilization and optimum utilization of God-given human resources which. A country where a functional education is not obtainable continuously extends its stay in the dark days of life and constantly keeps her citizens in the part of low level of quality of life as well as inconsistent standard of living. That is why the citizens of such a nation continues to be in slavery of other developed nations. It has been observed that functional education is a key factor in individual entrepreneurial and national development as well as a compass for national and individual direction. The quality of material products available in a nation for utilization by its people also depends on the quality of education they acquire. Therefore there is need to develop our education system and make it more functional in such a way that our younger generation would attach a high value to it. Developing the human capital of young Nigerians is vital if only to keep our dwindling economic growth. Our future entrepreneurs need the twenty-first century skills and knowledge to create successful ventures and to spur innovation in the Nigerian economy (Onyechi, 2914).

In the study of Odo, and Odo (2014), on teachers' perception of the need for functional computer laboratories in secondary schools in Nsukka education zone found that teachers' perception of the need for functional computer education was a positive one which did not depend on gender or educational qualification. It implies that the need for functional system of education in all sphere of education is a necessity in Nigeria as a country. In the present study, students' perception of functional education in Nigeria was found to be positive as well. It therefore becomes evident that functional education in Nigeria remains a vital tool for national development.

The attitude of students in this study have been found to be positively correlated with functional education. This implies that the more functional an educational is, the more students' attitude to that educational system remains positive. It also shows that the way students responds to any education, depends so much on the functionality of the system. Therefore, it has become imperative to ensure that Nigerian education system remains functionally stable. 


\section{Statement of the problem:}

There have been a great deal of outcry on the failing standard of education in Nigeria as well as the fact that our educational system is more of theoretical than practical as a result a lot of grounds have been lost since after the early days of Nigeria's independence. An educational system that was greatly admired everywhere, that attracted people from other nations to come to Nigeria to study. As at then Nigeria's education certificate was an object of pride. This was due to the performance of our ancestors in the field of education. Hence, the present state of education in Nigeria calls for the need to assess the students disposition on the impact of current educational system in Nigeria on the bases of its functionality, whether it meet their desire and aspiration.

\section{Objectives of the study:}

The objectives of the study are to assess the extent student teachers value Nigerian educational system, especially to determine their psychological disposition on the functionality of educational system in Nigeria.

\section{Hypotheses}

Ho1 There is no significant relationship between student's psychological disposition and functional education in Nigeria.

Ho2 There is no significant relationship between student's attitude and functional education in Nigeria.

Ho3 There is no significant relationship between the perception of students and functional education in Nigeria.

Ho4 There is no significant relationship on students' value for functional education and their psychological disposition.

Ho5 There is no significant difference in the mean scores of male and female students on their psychological disposition on functional education.

Ho6 There is no significant difference in the mean scores of students on their psychological disposition about functional education in Nigeria.

\section{Methodology:}

The research design used in the study is a simple descriptive survey design. This is a design that gives credence to the study of small and large population, their beliefs, opinions, attitudes, motivations, and behaviours. A simple random sampling system was used in selecting the participants in the study.

\section{Population of the study:}

The population of the study comprises of 200 level B.Ed student teachers of Ahmadu Bello University (ABU) Zaria and Uthman Danfodio University (UDU) Sokoto. 


\section{Instrumentation:}

The instrument used in the study is a questionnaire designed to assess the psychological disposition of the students on the functionality of Nigerian educational system. The instrument was validated by lecturers in measurement and evaluation in the department of Educational Psychology in Federal College of Education Zaria.

\section{Significance of the study:}

It is expected that student teachers will benefit from the result of the study, since it will boast their moral and confidence in the functionality of our educational system.

The outcome of the study will also help educators to fast track the training process of teachers since the emergent need in education will be exposed through the study. The result of the study will as well help educational planners to channel more attention towards making the educational system more functional. Professionals in the field of educational psychology will be in a better position in empowering students with more practical knowledge and skills.

\section{RESULTS:}

TABLE 1: DISTRIBUTION OF RESPONDENTS BY SEX

\begin{tabular}{lcc}
\hline SEX & FREQUENCY & PERCENTAGE \\
MALE & 92 & 46.0 \\
FEMALE & 108 & 54.0 \\
Total & 200 & 100 \\
\hline
\end{tabular}

The table above shows the sample size of 200 respondents according to gender. In essence, 92 are male representing $46 \%$, while 108 are female representing $54 \%$. TABLE 2: DISTRIBUTION OF RESPONDENTS BY COURSE OF STUDY 
International Journal of Education (IJE), Vol. 3, No. 3, September 2015

\begin{tabular}{lcc}
\hline Course of Study & Frequency & Percentage \\
Christian Religious study & 23 & 11.5 \\
Social Studies & 42 & 21.0 \\
Islamic Studies & 45 & 22.5 \\
Geography & 11 & 5.5 \\
English & 28 & 14.0 \\
Home Economics & 10 & 5.0 \\
Biology & 27 & 13.5 \\
Agric & 3 & 1.5 \\
Chemistry & 10 & 5.0 \\
Physical and Health Education 1 & & 0.5
\end{tabular}

Table two showed the statistical analysis of respondents based on their course of study. Christian Religious studies 23, representing $11.5 \%$, Social studies 42, representing 21\%, Islamic studies 45respondents, representing 22.5\%,Geography 11 representing 5.5\%, English 28, representing 14\%, of the respondents, Home Economics 10 representing 5\%, Biology 27 representing 13.5\%, Agric 3, representing 1.5\%,Chemistry 10, representing 5\% of the respondents, Physical and Health Education 1 representing $0.5 \%$ of the respondents.

\section{Hypotheses Testing:}

Hypothesis 1: There is no significant relationship between student's psychological disposition and functional education in Nigeria.

Table 3: Correlation analysis of respondents' assessment of Functional Education

\begin{tabular}{lrlllll}
\hline Variables & N & Mean & SD & r & df & Sig \\
Psychological disposition91.56 & 9.03 & & & & \\
$200 \quad .431^{* *} 198$ & .000 & & & & & \\
Functional education & & 36.70 & 3.99 & & & \\
\hline
\end{tabular}

\section{Level of significance $\mathbf{r}=\mathbf{0 . 0 1}$}

Table 3; shows the correlation analysis of respondents' assessment of functional education in Nigeria. The study revealed a significant relationship between the respondent's psychological disposition and functional education in Nigeria. This is due to the fact that the significant level of 0.000 is less than 0.05 significant level of tolerance at a correlation $r$ level of $.431 * *$ Therefore, the null hypothesis which states that there is no significant relationship is hereby rejected . 
International Journal of Education (IJE), Vol. 3, No. 3, September 2015

\section{Hypothesis 2:}

There is no significant relationship between student's attitude and functional education in Nigeria.

Table 4: Correlation analysis of respondents' attitude towards functional education

\begin{tabular}{lccccc}
\hline $\begin{array}{l}\text { Variables } \\
\text { Attitude }\end{array}$ & & $\mathbf{N}$ & $\begin{array}{c}\text { Mean } \\
13.55\end{array}$ & SD & r \\
$200.580^{* *}$ & 198 & .003 Functional education & & df & Sig \\
\hline
\end{tabular}

\section{Level of Significance $\mathbf{r}=\mathbf{0 . 0 1}$}

The correlation analysis in table 4 shows a significant relationship between the attitude of respondents and functional education in Nigeria. Hence the calculated level of significance of 0.000 is less than the 0.05 level of tolerance at a correlation level of $.431^{* *}$. Hence, the null hypothesis is thereby rejected.

\section{Hypothesis 3:}

There is no significant relationship between the perception of students and functional education in Nigeria.

Table 5: Correlation analysis on the perception of respondents on functional education in Nigeria

\begin{tabular}{lccrccc}
\hline Variables & N & Mean & SD & r & df & Sig \\
Perception & & 27.95 & 4.25 & & & \\
& 200 & & & $.847 * *$ & 198 & 0.000 \\
Functional Education & & 91.56 & 9.03 & & & \\
\hline
\end{tabular}

\section{Level of significance $\mathbf{r}=\mathbf{0 . 0 1}$}

Data in Table 5 shows the correlation analysis of students' perception of functional education in Nigeria. The study revealed that significant relationship exists between student's perception and functional education in the country. The calculated level of significance of 0.000 is less than the 0.05 level of tolerance at a correlation index $r$ level of $.848^{* *}$. Therefore, the null hypothesis that states that there is no significant relationship is hereby rejected.

\section{Hypothesis 4:}

There is no significant relationship between students' value for functional education and their psychological disposition. 
International Journal of Education (IJE), Vol. 3, No. 3, September 2015

Table 6: Correlation analysis on the value respondents placed on functional education in Nigeria

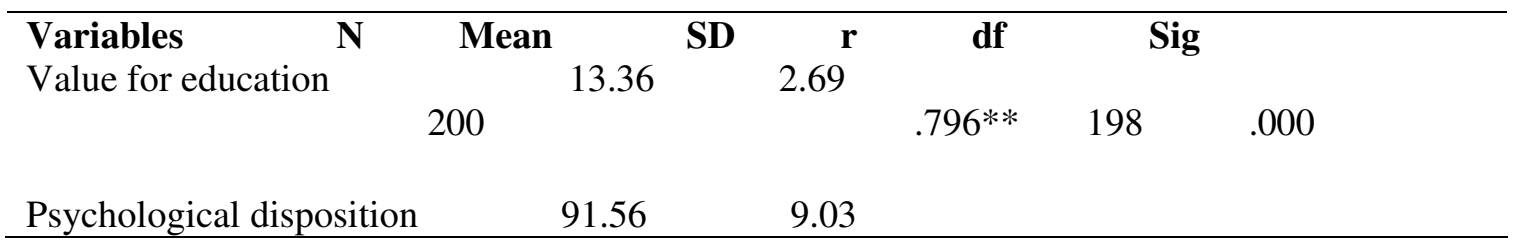

\section{Level of significance $\mathbf{r}=\mathbf{0 . 0 1}$}

Data in Table 6 shows the correlation statistics of the value respondents placed on functional education in Nigeria. The calculated level of significance is 0.000 and it is less than the 0.05 level of tolerance at the correlation $\mathrm{r}$ level of $.796^{* *}$. Therefore, the null hypothesis is hereby rejected.

\section{Hypothesis 5:}

There is no significant difference in the mean scores of male and female students on their psychological disposition on functional education.

Table 7: $\mathrm{t}$ - test statistical analysis on the difference in the mean scores of Male and Female Respondents on Functional Education in Nigeria

\begin{tabular}{lccccccc}
\hline Gender & $\mathrm{N}$ & Mean & SD & df & T Cal & t - Crit & Sig \\
Male & 92 & $91 . .21$ & 8.14 & & & & \\
& & & & 198 & .510 & 1.96 & .611 \\
$\begin{array}{l}\text { Female } \\
\text { Total }\end{array}$ & 108 & 91.86 & 9.76. & & & & \\
\hline
\end{tabular}

$\mathrm{P} \geq 0.05$ The $\mathrm{t}-$ test analysis in table 7 , revealed that there is no significant difference between male and female respondents on functional education in Nigeria. This is evidenced in the fact that calculated $p$ value of .611 is higher than the 0.05 level of significance. The calculated t value is .510 and it is less than t critical of 1.96 . Hence, the null hypothesis which states that there is no significant difference in mean scores of male and female respondents on functional education is accepted.

\section{Hypothesis 6:}

There is no significant difference in the mean scores of students on their Psychological disposition about functional education.

Table 8: Analysis of variance on the mean scores of students respondents on the basis of their course of study

\begin{tabular}{lcccccc}
\hline Variables & Sum of Squares & $\mathrm{df}$ & Mean Square & $\mathrm{F}$ & F cal & Sig \\
Between groups & 911.56 & 9 & 101.29 & & & \\
& & & & 1.26 & 2.60 & .263 \\
Within groups & 15317.72 & 190 & 80.620 & & & \\
Total & 16229.28 & 199 & & & & \\
\hline
\end{tabular}


International Journal of Education (IJE), Vol. 3, No. 3, September 2015

Data in Table 8 shows the Analysis of Variance (ANOVA) on the differences in the students views about functional Education in Nigeria based on their course of study. The study revealed that there is no significant difference among them in their views on functionality of education in Nigeria. The calculated significant value of .263 is higher than the significant level 0.05 . Also the calculated value of $\mathrm{F}$ ratio is less than $2.60 \mathrm{~F}$ critical. Hence, the null hypothesis is hereby retained.

\section{Discussion:}

A test relationship was carried out on the psychological disposition of students on functional education in Nigeria. The result of the study has revealed vital issues that have implication on the functionality of education in the country. The issues revealed here are very critical to the belief in and conviction in the fact that education in Nigeria contains basic elements of functionality. The result of the study showed that students at different levels of academic endeavour value the educational system in Nigeria. This is demonstrated through the outcome of hypothesis one which revealed significant relationship between their psychological disposition and functional education. That position tends to agree with the assertion of Arko and Addison (2009) which states that developed and developing countries recognize the fact that formal education is a prerequisite for growth and development and so they try to provide quality formal education for their citizens. Molagun (2008) study showed $16.5 \%$ of his respondents in answering the question whether Nigerian educational system has taken adequate care of the promotion of function al education affirms that Nigerian educational system is practical based.

Table 4 showed that significant relationship exists between students' attitude and functional education. This is a pointer to a positive attitude of students towards the level of functional education obtainable in the country. The study also revealed a significant relationship between students' perception and functional education in Nigeria. This shows that students view the functionality of education in the country from a positive perspective contrary to the general view.

The study further revealed that student teachers value the functional level of education obtainable in the country. This is evidenced in the fact that a significant relationship exists between the value students placed on the functionality of education in the country which is an aspect of their psychological disposition and the functionality of education. This finding disagrees with finding of Molagun (2008) which shows that $76.7 \%$ of his respondents' disagree with the notion of function al education in Nigerian educational system. In essence, the opinions of students generally about the functionality of education in the country do not differ. This is shown in the fact that there is no significant difference in the perception, attitude and value placed on the functional system of education in Nigeria between male and female students in their views about functional education in the country. This also happens when analysis of variance was carried out on the basis of their course of study, their opinion remains constant.

\section{Conclusion:}

In essence, the study has to a great extent portrayed a positive light on the way Nigerian student teachers value education in Nigeria. It is evidenced here that Nigerian student teachers show good level of appreciation of the level of functionality of education which is obtainable in the country. 
International Journal of Education (IJE), Vol. 3, No. 3, September 2015

The students value for this kind of education is seen to be very positive. Furthermore, their perception for the functional level of education in Nigeria also follows the process of their value system. This seems to imply that the way students look at the educational system in Nigeria indicates that their perception about the educational system to some extent is appreciable.

\section{Recommendations:}

As a result of the outcome of the study, the following recommendations were made.

1. The more functional the educational system in the country is, the more students' positive attitude to it should be. Hence it is highly recommended that Nigerian education should be made more functional than as it is presently.

2. Since students place positive value on the educational system in Nigeria, their value system should be enhanced by increasing the functional level of the education system in order to help them sustain the tempo.

3. In as much as the students' perception towards education in Nigeria is positive, more of the elements that make education functional in a country should be introduced into the system, especially teacher training process in order to make it more viable, acceptable, and attractive.

4. Educational planners, administrators, government agencies, and other stakeholders in the education industry should note this development and collaborate to ensure that the functionality level of the country's education system is upgraded and made more responsive to yearnings and aspirations of Nigerians.

\section{References:}

[1] Addo-Adeku, K. (1992) A case study of functional literacy programme in the Ga district, greater Accra region of Ghana. Ghana Journal of Literacy and Adult Education. 1(2), 167-182. in Arko09

[2] Arko, A. D. \& Addison, K. (2009). The impact of functional literacy on socioeconomic lives of beneficiaries: A case study of the Agona Distric of Ghana. Edo Journal of Counselling,2 (2), 199 - 213.

[3] American Heritage English dictionary (2009). Houghton Mifflin Company. Chima, I. (2007). Enhancing morality in Nigerian youths through moral education and counseling for national development. Journal of the Nigerian Society for Education Psychologists (NISEP), 5, 31 - 37.

[4] Collins English Dictionary (2003). Harper Collins Publishers. In The Free dictionary. http://www.the freedictionary.com

[5] Echoda, P. A. (2009). Journal of Curriculum studies and Instruction FCT Abuja. Elombach, D. (2010). Functional education in a global economy. Retrieved from http://www.mail.elombach.com/index.php/articles/daniel-elomach/40194.

[6] Freire, P. (1992) Cultural action for freedom. London: Penguin.

[7] Molagun, H. M. (2008). An investigation into the problems inhibiting the effective promotion of functional education in Nigerian schools: A case study of KwaraState secondary Schools. African Journal of Historical Science in Education, 4(1\&2), 158 - 169

[8] Nayak, A. K. \& Rao, V. K. (2004). Educational Psychology. New Delhi: APH Publishing Corporation.

[9] Obinne, A.D.E. \& Adikwu, O. (2007). Factors influencing the aspirations of the Nigerian child: An experience from BenueState. The Journal of the Nigerian Society For Educational Psychologists (NISEP), 5, 112 - 119 . 
International Journal of Education (IJE), Vol. 3, No. 3, September 2015

[10] Rehab management, (2012). Functional Education. Retrieved January 2013 from http://www.rehabmanagement.com.au/functiiional-education.

[11] The Free dictionary (2013). Retrieved from the freedictionary.com /disposition.

[12] The Politico, (2011). Reviving functional education in Nigeria. Retrieved January 2013 from http://www.the-politico.com/development/reviving-functionaleducation-in-nigeria.

[13] Ukoha, E. K. (2007). The home as a factor in laying the foundation for value, for Educationin Nigerian children. Journal of Nigerian Society for Educational Psychologists (NISEP), 5, 84 - 91.

[14] Zeilberger, Y. (1999). Functional Education. Retrieved January 2013 from http://www.iuacth.retgws.educ/zeilberger/?family.

[15] Dorvlo, L. T. K. (1992). Some fundamental issues in functional literacy. Ghana Journal of Literacy and Adult Education, 1(1), 15 - 28. 